\title{
THE FRAMEWORK TO MITIGATE THE URBAN HEAT ISLAND EFFECT FOR IMPROVING ENVIRONMENT AND PROTECTING HUMAN HEALTH
}

\author{
P. SHAHMOHAMADI, A.I. CHE-ANI, K.N.A. MAULUD, A. SAIRI \& M.F.I. MOHD-NOR \\ Department of Architecture, Faculty of Engineering and Built Environment, Universiti Kebangsaan Malaysia, \\ 43600 UKM Bangi, Selangor, Malaysia.
}

\begin{abstract}
Changes in temperature and precipitation, sea level, fisheries, agriculture, natural ecosystems, and air quality will all directly or indirectly affect human morbidity (illness) or mortality. One of the great challenges facing our current generation of scientists and engineers is how to protect urban population from health stressors associated with summertime heat. As heat-waves are likely to increase in frequency because of global climate change, the most effective interventions, measures and policies to protect the health need to be developed and evaluated. Therefore, this paper is focused on understanding the most important factors of urban heat island (UHI) formation and their effects on urban population health with an emphasis on the considerable growth of both population and rapid urbanization of Tehran, Iran. To achieve this aim, this paper explores literally a conceptual framework about the relationship between UHI and human health. Then, it suggests three important strategies to minimize the impact of UHI on human health: achieving appropriate transportation for mitigating air pollution, providing appropriate landscape, increasing the albedo of building materials.

Keywords: appropriate landscape, appropriate material, appropriate transportation, human health, natural ventilation, urban heat island.
\end{abstract}

\section{INTRODUCTION}

Climate change is a global phenomenon that leaves no part of the world untouched. Everywhere, changes in climate are having observable impacts on both natural and human systems - water resources, ecosystems, food and forest products, coastal systems, industry, settlements and societies, and human health, involving significant social, economic and environmental consequences [1].

Climate change presents significant challenges in efforts to maintain and improve the health and well-being of people living around the world. Many of the environmental hazards exert a direct or indirect effect on the health and well-being of urban dwellers. One of the most important hazards which impact on health and quality of life is 'urban heat island'. Urban heat island (UHI) can directly affect health because high temperatures place an added stress on human physiology. UHI will have wide-ranging impacts on society and the infrastructure that support civilization. It could impact not only agricultural and human health, but also patterns of human settlement, energy use, transportation, industry, environmental quality, and other aspect of infrastructure that affect our quality of life [2].

According to the above perspective it becomes increasingly important to apply heat island mitigation strategies in order to protect human health from health stressors associated with summer time heat.

Thus, this paper investigates that which factors cause UHI formation, especially in Tehran metropolitan, and then by recognizing some factors which have more effects on health, suggests some solutions from urban design perspective in order to have healthy environment.

\section{URBAN HEAT ISLAND}

The majority of cities are sources of heat and pollution, and the thermal structure of the atmosphere above them is affected by the 'heat island' effect. A heat island is best visualized as a dome of stagnant warm air over the heavily built-up areas of cities [3]. The heat that is absorbed during the day by the buildings, roads and other constructions in an urban area and is re-emitted after sunset, creating high 
temperature differences between urban and rural areas [4]. There are some factors in formation of UHI over the city studied as following.

\subsection{Factors in formation of urban heat island}

In studying the effects of UHI on health, it is important to distinguish some factors which cause the heat island phenomenon. UHIs are caused by differences in the radiative, thermal, moisture, and aerodynamic properties of urban and rural surface covers [5]. Oke [6] incorporated these causes into the following five categories (not ranked), each of which represents change to the pre-urban environment brought about by urbanization (sources and causes of these factors are summarized in Table 1):

1. air pollution;

2. anthropogenic heat;

3. surface 'waterproofing';

4. thermal properties of fabric; and

5. surface geometry.

Table 1: Factors in the formation of urban heat island.

\begin{tabular}{|c|c|c|}
\hline Factors & Sources & Causes \\
\hline Air pollution & $\begin{array}{l}\text { Emissions of particulates, } \\
\text { water vapor, carbon dioxide } \\
\text { from industrial, domestic, } \\
\text { and automobile combustion } \\
\text { processes }\end{array}$ & $\begin{array}{l}\text { 1. Reducing the incident flux of short-wave } \\
\text { (i.e. solar) radiation. } \\
\text { 2. Re-emitting long-wave (i.e. infrared) } \\
\text { radiation from the urban surface downward } \\
\text { to where it is retained by the ground. } \\
\text { 3. Absorbing long-wave radiation from the } \\
\text { urban surface, effectively warming the } \\
\text { ambient air. }\end{array}$ \\
\hline $\begin{array}{l}\text { Anthropogenic } \\
\text { heat }\end{array}$ & $\begin{array}{l}\text { Space heating, manufacturing, } \\
\text { transportation, lighting and human } \\
\text { and animal metabolisms }\end{array}$ & $\begin{array}{l}\text { Warms the urban atmosphere by } \\
\text { conduction, convection, and radiation }\end{array}$ \\
\hline $\begin{array}{l}\text { Surface } \\
\text { 'waterproofing' }\end{array}$ & $\begin{array}{l}\text { The predominance } \\
\text { of impermeable surface } \\
\text { in urban areas }\end{array}$ & $\begin{array}{l}\text { 1. Buildings and paved streets quickly shed } \\
\text { precipitation into catchment basins, } \\
\text { creating an evaporation deficit in the city. } \\
\text { 2. Urban surface cover enhances sensible heat } \\
\text { transfer and suppresses latent heat flux. }\end{array}$ \\
\hline $\begin{array}{l}\text { Thermal properties } \\
\text { of fabric }\end{array}$ & $\begin{array}{l}\text { Urban construction materials } \\
\text { such as concrete and asphalt }\end{array}$ & $\begin{array}{l}\text { The greater diurnal absorption of short-wave } \\
\text { radiation in urban areas }\end{array}$ \\
\hline Surface geometry & $\begin{array}{l}\text { The complex geometry of urban } \\
\text { surfaces }\end{array}$ & $\begin{array}{l}\text { 1. Increased friction created by a rough } \\
\text { urban surface reduces horizontal } \\
\text { airflow in the city. } \\
\text { 2. The complex geometry of the urban } \\
\text { surface changes the urban radiation budget. } \\
\text { During the day vertical canyon walls trap } \\
\text { short-wave radiation. Night-time losses of } \\
\text { infrared energy are also retarded due to the } \\
\text { decreased sky view below roof level. }\end{array}$ \\
\hline
\end{tabular}


This brief explanation of UHI genesis is based on the assumption that meteorological conditions are ideal for its formation. Ideal weather conditions are generally satisfied by cloudless skies and light several hours after sunset [5]. Open skies provide a radiative sink that allows for maximum long-wave radiation losses from rural surfaces, and weak winds reduce the turbulent mixing of urban and rural air. Together these conditions promote maximum urban-rural thermal differences.

\subsection{Urban heat island analysis}

\subsubsection{The case of Tehran}

This paper investigates the most important factors of UHI formation in Tehran city. Tehran's urban area, with 12 million inhabitants, between Alborz mountains in the north and Dasht-e-Kavir in the south, is located on a vast mountain slope with an altitude of 900-1,700 $\mathrm{m}$ from the sea level [7]. Figure 1 shows satellite images of Tehran, with its 22 urban districts, including the industrial and residential areas west of Mehrabad airport.

Increasing urbanization and industrialization in Tehran metropolitan in recent decades have caused the urban environment to deteriorate [8]. Tehran suffers from raised temperatures in the city core, generally known as the heat island effect. Raised temperatures, especially in summer, turn Tehran city center into unwelcome hot areas, with direct effects on energy consumption for cooling buildings and morbidity and mortality risks for the population. These raised temperatures in the Tehran city centre derive from the altered thermal balances in urban spaces, mainly due to the materials and activities taking place in the city, by far different to those in rural areas. The increasing numbers of buildings and construction in Tehran have crowded out vegetation and trees. Thus, air temperature increases especially in high density areas. The general lack of vegetation and the low albedo of urban surfaces are strong characteristics of the formation of the heat island effect in Tehran metropolitan. The geometry between a vegetated area and the density-morphology of an urban area is completely different, which has a direct effect on wind and shade distributions. Human activities taking place in Tehran urban areas are responsible for anthropogenic heat release (transport, space and water heating, cooling, etc.) and air pollution, the latter affecting clouds cover [8]. The combination of these factors

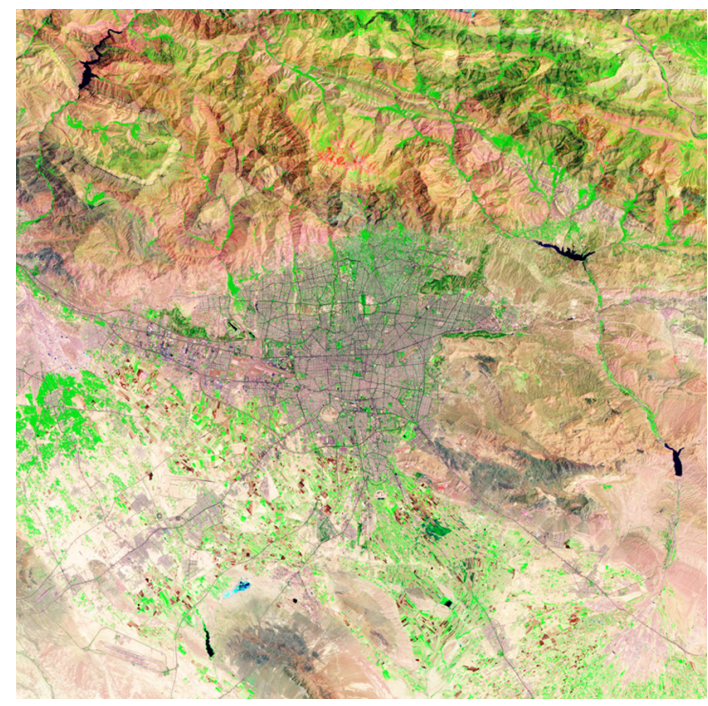

Figure 1: Tehran satellite image (NASA). 
determines the way in which heat is absorbed, stored, released and dispersed in the urban environment, expressed as a temperature increase in the urban area.

According to the Oke's factors division in the formation of UHI [6] (as described above), this article will explain the roles of these factors in the formation of Tehran UHI in the following way:

\section{Air pollution}

Tehran with population of approximately 12 millions and with a metropolitan area of around $800 \mathrm{~km}^{2}$ is the center of the national government and of commercial, financial, cultural and educational activities in Iran [9]. Rapid urban expansion over the past two decades in Tehran resulted from a high population growth rate and increased rural urban migration combined with a strong tradition of centralization in the capital [10].

Air pollution is one of the more recent problems in Tehran threatening the health of its inhabitants. This problem has become worse due to the high urban population (Fig. 2). Tehran's air pollution problem is severe by world standards and the government of the Islamic Republic of Iran has identified it as a high priority environmental and health issue. It is known that between 65 and $70 \%$ of total emissions are related to urban transport operations. Reported average concentrations of pollutants such as carbon monoxide (CO), particulate matter less than $10 \mu \mathrm{m}$ diameter (PM-10) and sulfur dioxide $\left(\mathrm{SO}_{2}\right)$, in the city center in 1998, were two to three times above average levels recommended by WHO/USEPA [11]. The growth in number of vehicles over the last 2 years has made the situation even more severe (Table 2).

The problem is compounded by topographical (mountains to the north and the east) and climatological factors (sunshine, frequent temperature inversions), which favor photochemical transformation of volatile organic compounds (VOCs) and nitrogen oxides (NOx) to produce smog and tropospheric ozone. There are enough reasons to believe that the city suffers from high ozone concentration levels [11].

In summer time, compared with other seasons, air pollution is more severe, since in other seasons there is more wind and rain. But in cold seasons, when the phenomenon of inversion occurs, the cold air of higher layers prevents the warm and polluted air to rise and this maximizes the air pollution leading to a crisis. On the contrary, lack of winds in summer causes a worse air pollution. Crisis or emergencies, however, are rare in summer [7].
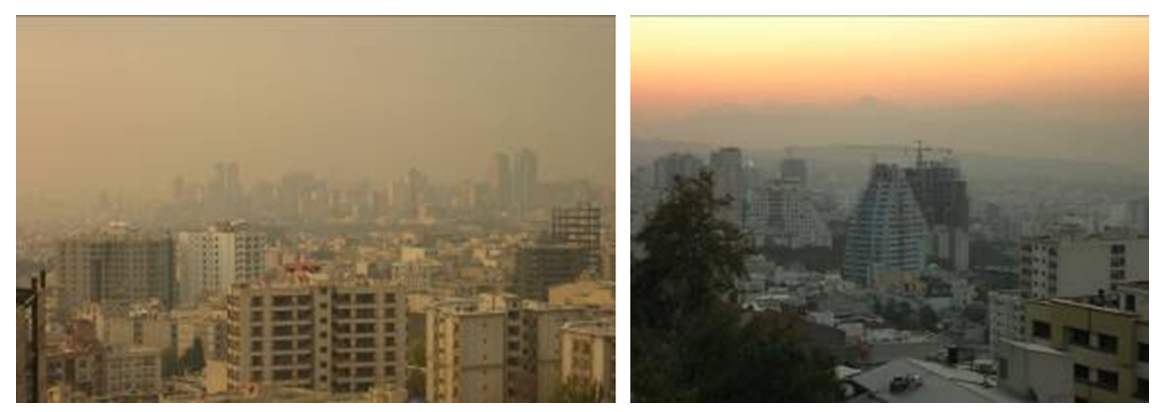

Figure 2: Air pollution in Tehran.

Table 2: Annual average concentration of air pollutant in Tehran metropolitan [11].

\begin{tabular}{lcccc}
\hline & $\mathrm{CO}(\mathrm{ppm})$ & $\mathrm{NO}_{2}(\mathrm{ppb})$ & $\mathrm{SO}_{2}(\mathrm{ppb})$ & $\mathrm{PM}-10\left(\mu \mathrm{g} / \mathrm{m}^{3}\right)$ \\
\hline Average in 1999 & 9 & 39 & 48 & 112 \\
Estimated in 2010 & 26 & 300 & 200 & 200 \\
WHO/EPA standard & $2-4$ & 50 & 30 & 50 \\
\hline
\end{tabular}


Alijani and Safavi [9] have mentioned that there are various factors in Tehran metropolitan that complicate the overall environmental situation. These factors include: topography, climate, population, industry and urban transportation (summarized in Table 3).

\section{Anthropogenic heat}

Anthropogenic heat discharge in a city also contributes to the UHI effect. Sources of anthropogenic heat include space heating, manufacturing, transportation, and lighting. Human and animal metabolisms are

Table 3: Effective factors on Tehran air pollution.

\begin{tabular}{|c|c|c|}
\hline Factors & Explanation & Effects on air pollution \\
\hline Topography & $\begin{array}{l}\text { Topography direction is to the south } \\
\text { City is surrounded from two sides } \\
\text { by mountains (North and East) } \\
\text { Prevailing wind is from West }\end{array}$ & $\begin{array}{l}\text { North and East mountains prevent taking } \\
\text { out the air pollution which is brought by } \\
\text { West prevailing into the urban spaces } \\
\text { and it is caused to pollute the weather } \\
\text { especially in East and Central areas. } \\
\text { Increasing inversion in Tehran }\end{array}$ \\
\hline Climate & $\begin{array}{l}\text { Climate controls the Tehran air } \\
\text { pollution conditions by differences } \\
\text { in temperature, rain, pressure } \\
\text { and wind }\end{array}$ & $\begin{array}{l}\text { Increasing temperature in the Central } \\
\text { Tehran cause UHI. UHI leads pollutions } \\
\text { from suburb to the city by wind flow } \\
\text { Although raining cleans the air, it leaches } \\
\text { pollutions in the air and sediments in soil } \\
\text { Settling industry in west cause prevailing } \\
\text { wind to bring pollutions from West to the } \\
\text { Central Tehran } \\
\text { In winter, when the phenomenon } \\
\text { of inversion occurs, the cold air of higher } \\
\text { layers prevents the warm and polluted air } \\
\text { to rise and this maximizes the air } \\
\text { pollution leading to a crisis } \\
\text { High pressure pattern in Tehran provide } \\
\text { stable weather and pollutions cannot } \\
\text { raise and the weather is polluted }\end{array}$ \\
\hline Population & $\begin{array}{l}\text { Tehran population is around } \\
12 \text { millions in day and } 8 \text { million } \\
\text { at night }\end{array}$ & $\begin{array}{l}\text { Higher population annually increase } \\
\text { millions kilo calorie energy in urban } \\
\text { thermal temperature from biological } \\
\text { activities. Producing lots of energy } \\
\text { from these activities cause UHI }\end{array}$ \\
\hline Industry & Industries settle in the West of Tehran & $\begin{array}{l}\text { Settling industry in unsuitable place and } \\
\text { not considering hygiene rules are causing } \\
\text { Tehran air pollution } \\
\text { West and South western prevailing winds } \\
\text { lead factories surplus materials to the city }\end{array}$ \\
\hline $\begin{array}{l}\text { Urban } \\
\text { transportation }\end{array}$ & $\begin{array}{l}\text { About } 3 \text { millions motorcars operate } \\
\text { in an extremely congested } \\
\text { road space (according to } 2007 \\
\text { statistical data) }\end{array}$ & $\begin{array}{l}\text { Current air pollution is mostly due to heavy } \\
\text { traffic of motorcars and its geographic } \\
\text { location depends on winds that disperse } \\
\text { it or lack of winds that let it remain }\end{array}$ \\
\hline
\end{tabular}


also considered sources of artificial heat [12]. Heat from these sources warms the urban atmosphere by conduction, convection, and radiation [6].

Anthropogenic heat is a quite crucial factor in the Tehran heat island effect, because the per capita energy use and the population density are high. In certain high density areas, anthropogenic heat release can be equal to or even more than the solar input in winter and on some occasions in summer also, because of the high use of air conditioning systems [13].

Due to human activities in the urban environment a lot of particulates are produced, mostly by industry, vehicles and the burning of fossil fuels for heating, cooling or electricity generation. The significance of each source varies according to the characteristics of each city [13]. In Tehran the major sources are (1) heat generation by cooling and heating buildings, respectively, in hot summer and cold winter; (2) industrial heat generation; (3) energy use in transportation.

High density of buildings and population in Tehran, especially in the center and south areas, has increased amount of energy consumption. It goes without saying that increasing large number of buildings and population cause that all the energy consumed by air conditioning is eventually released to the environment, elevating the urban temperature (Fig. 3).

Industrial heat generation in Tehran also contributes to the UHI. The most of Iranian industries manufacturing automobiles, electrical equipment, military weaponry, textiles, sugar, cement, and chemical products, are headquartered in Tehran. There are more than 7,000 industrial units in Tehran which have been established 30\% in West, 54\% in South and 16\% in East [9]. Therefore, since Tehran has been surrounded with these industrial units, all the energy consumed by these industries is converted into heat, contributing to the UHI.

The other source which contributes to the Tehran UHI is energy use in transportation. The contribution of energy use in transportation to the heat island may be related to the size and the relative role of public transportation in it. It can be assumed that larger cities have more overall traffic, but the trips, and the energy they consume, are distributed over a larger area. However, more people and trips are concentrated in the center of larger cities, as compared with smaller cities. Thus energy input by transportation at the town's center may be related to the size of the city. This effect may be modified by the type of the urban transportation system. Private cars consume more fuel and generate more heat, per passenger, than buses and electrical subway [14].

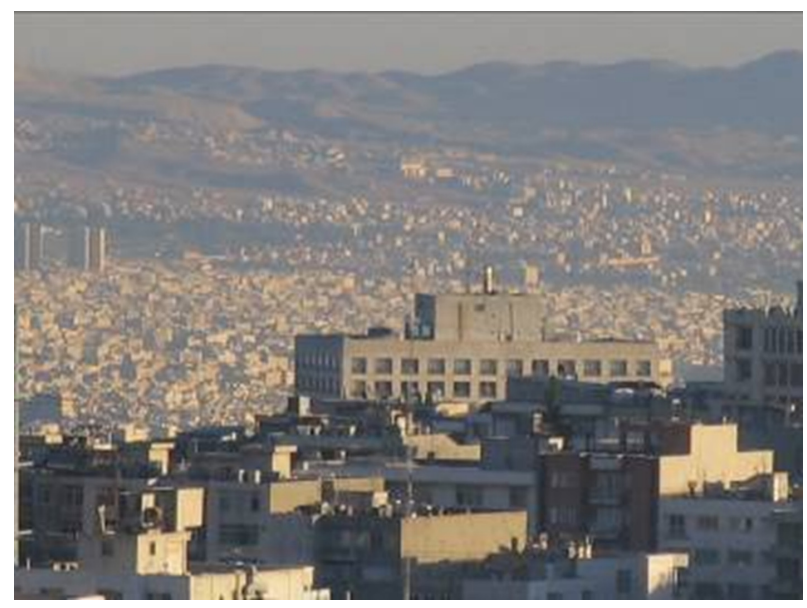

Figure 3: High density of buildings in Tehran and increasing anthropogenic heat generation. 
Tehran has a poor public transportation network. With considerable growth of population, buses and metros cannot cover every area of the city. Most people are then obliged to use private cars which have created severe traffic congestion. Tehran city size is also large which has more overall traffic. Using private unmanned cars in large scales cause the cars to consume more fuel and generate more heat (Fig. 4).

\section{Surface waterproofing}

In rural areas which are attractive for human habitats, their main characteristic is the existence of vegetation, which tends to be a secondary characteristic in the urban environment. The existence of vegetation modifies the local climate, due to the latent heat flux produced by plants. The surface temperature of plants is usually not significantly different to ambient air temperature. Furthermore, they are also able to cause further cooling through evapotranspiration, the combined procedure of evaporation and transpiration happening simultaneously at the vegetal surface. When evapotranspiration occurs, a certain amount of water is lost from a cropped surface. The energy (heat) required to vaporize water is known as the latent heat of vaporization. This energy consumed during evapotranspiration is responsible for lowering the temperature of the air in the vicinity of plants. Apart from plants and water surfaces, porous surfaces, which absorb water (e.g. soil) account for quite significant latent heat flux in the atmosphere. Materials mostly used in the urban texture are generally waterproof. Rainwater in cities is mostly channeled away from the city system through sewers and not through latent flux from the surface [13].

Lack of porosity materials in urban surfaces and natural vegetation in Tehran has created an evaporation deficit in the city which caused the intensity of UHI. Destroying vegetation and green spaces and constructing new buildings instead and covering the urban spaces with waterproofing and low albedo materials increase air temperature. If building surfaces, which are greatly responsible for

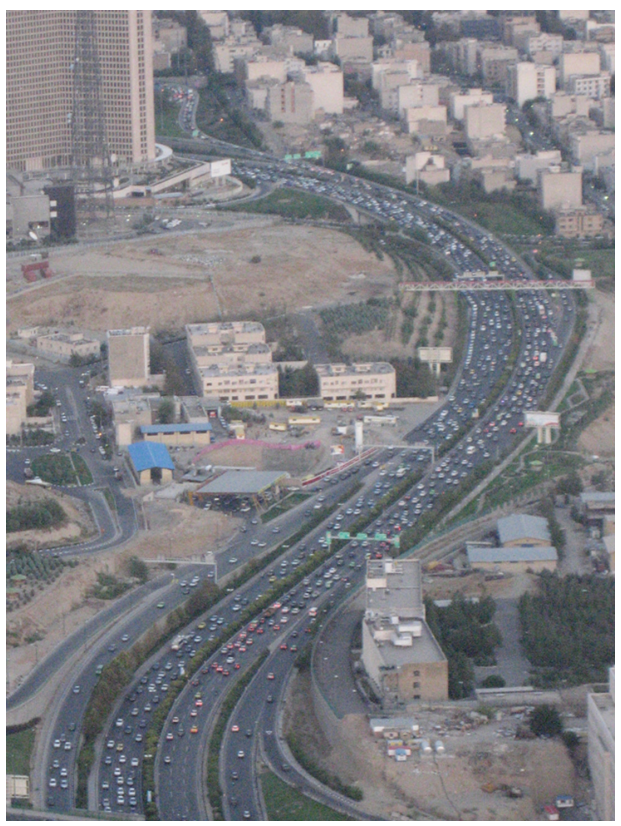

Figure 4: Traffic congestion in high way, Tehran. 
the formation of raised urban temperatures are covered with either high albedo materials or vegetation it is expected that urban temperatures could lower significantly.

\section{Thermal properties of fabric}

The heat capacity, and consequently thermal inertia, of urban construction materials such as concrete and asphalt is greater than that of natural materials found in rural environments. A greater heat capacity means that urban materials absorb and retain more solar radiation than rural soils and vegetation [6].

By considering that the most of urban construction materials in Tehran are concrete and asphalt, these materials absorb and retain solar radiation in Tehran urban fabric [15]. At night, this stored heat is released slowly from the urban surface, contrary to the rapid heat escape from rural surfaces. Thus, the UHI intensity peaks several hours after sunset when rural surfaces (and consequently surface air temperatures) have cooled yet urban surfaces remain warm. If the difference in heating rates is great enough, rural air temperatures may equal or exceed urban temperatures. This reduces the UHI intensity to a daytime minimum, and may even generate an urban cool island [5].

Reflection of short-wave solar radiation is also affected by the properties of the urban fabric. Urban albedos are, on average, 5-10\% lower than rural values [16]. This contributes to the greater diurnal absorption of short-wave radiation in urban areas.

\section{Surface geometry}

The way of construction in city (urban form), which prevents transferring air, especially in high density fabrics of the Central Tehran, causes UHI [8] (Fig. 5).

The complex geometry of Tehran urban surfaces is due to increasing air temperatures. Increased friction created by a rough urban surface reduces horizontal airflow in the city. Mean annual wind speeds within cities are approximately 30-40\% lower than mean annual wind speeds in the countryside [16]. Warm air stagnates in the urban canyons unless ventilated by cool rural air. Lower wind speeds in the city also inhibit evaporation cooling. The complex geometry of the urban surface changes the urban radiation budget. During the day, vertical canyon walls trap

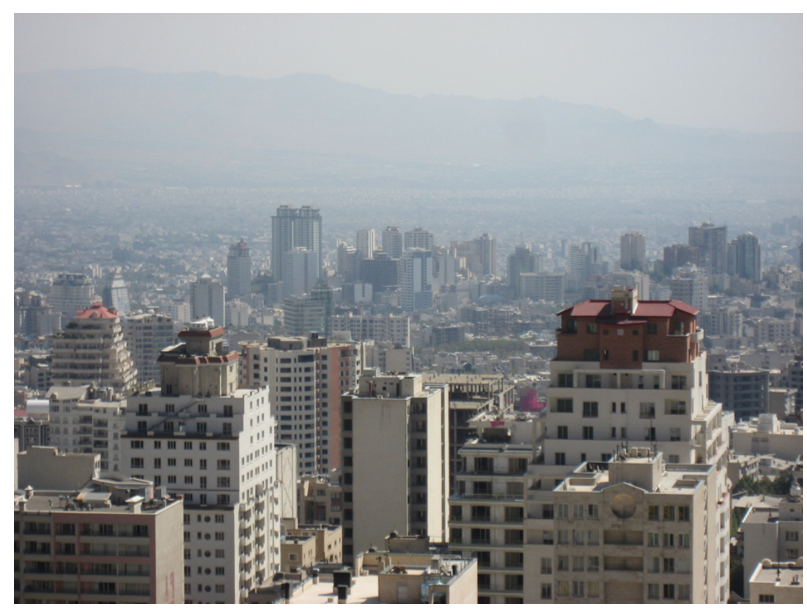

Figure 5: High density fabrics in Tehran. 
(i.e. reflect and absorb) short-wave radiation. Night-time losses of infrared energy are also retarded due to the decreased sky view below roof level. Rural surfaces, on contrary, are comparatively smooth and therefore experience greater nocturnal radiative flux divergence than complex urban surface.

\section{CONCEPTUAL FRAMEWORK: EFFECTS OF URBAN HEAT ISLAND ON HUMAN HEALTH}

UHI may have some negative impacts on air quality, human health and cooling energy consumption in cities. Although all these impacts are important, this paper focuses only on the effects of UHI on human health.

UHI exerts a direct or indirect effect on the health and well-being of urban dwellers. Heat island can directly affect health because high temperatures place an added stress on human physiology. Changes in temperature and precipitation including extreme weather events can cause deaths directly or by altering the environment, which result in an increased incidence of infectious disease. Air pollution can be exacerbated by higher temperature and humidity [17]. UHI effect increases the possibility of the formation of smog which is created by photochemical reactions of pollutants in the air. The formation of smog is highly sensitive to temperatures since photochemical reactions are more likely to occur and intensify at higher temperatures. Atmospheric pollution can be aggravated due to the accumulation of smog. In addition, the increased emissions of ozone precursors from vehicles and vegetation are also associated with the high ambient temperature. The UHI effect also involves the hazard of heat stress related injuries which can threaten the health of urban dwellers [18].

Figure 6 shows the most important factors of UHI formation, urbanization factors, and also the impacts of climate condition on urbanization to increase the UHI intensity. Therefore, the formation of UHI over the city affects human health, air quality, and energy consumption.

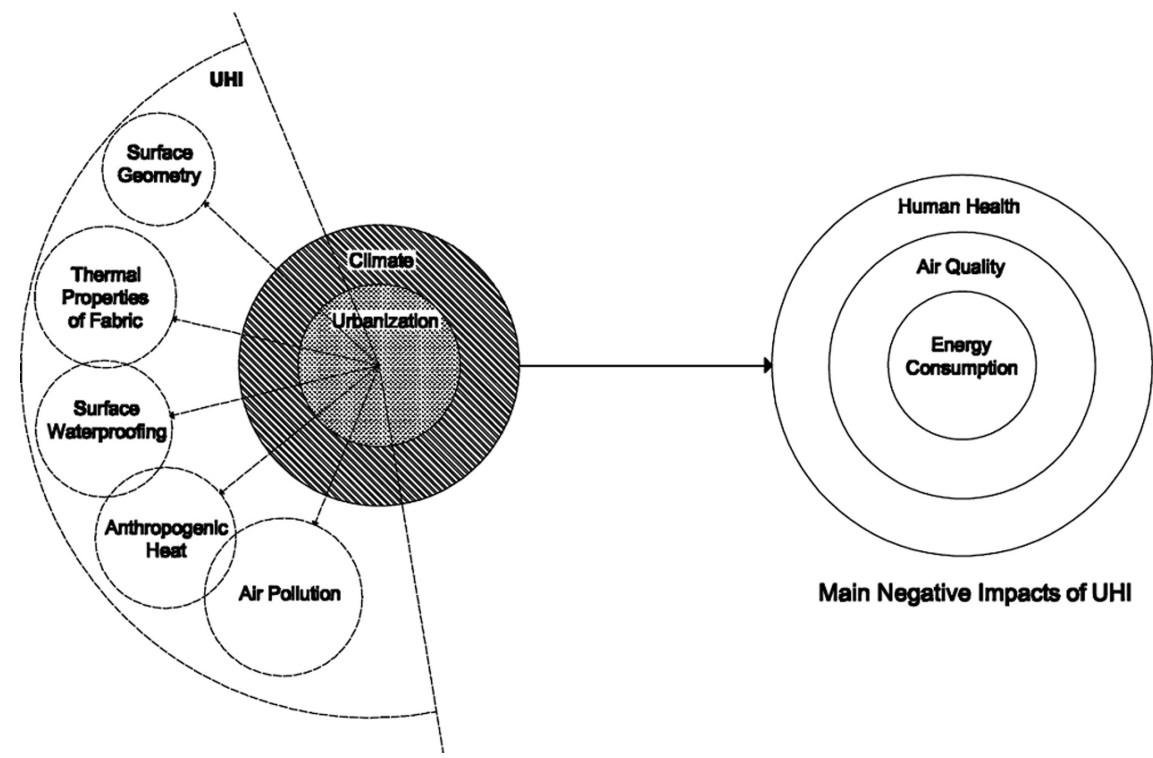

Figure 6: The effect of urbanization factors on the formation of UHI and its negative impacts. 
Table 4: Environmental factors and their effects on the human heat balance [19].

\begin{tabular}{|c|c|c|}
\hline $\begin{array}{l}\text { Environmental } \\
\text { factors }\end{array}$ & $\begin{array}{l}\text { Effect on human } \\
\text { heat balance }\end{array}$ & Explanation \\
\hline Air temperature & $\begin{array}{l}\mathrm{T}(\text { skin })>\mathrm{T} \text { (air) } \\
\mathrm{T}(\text { skin })<\mathrm{T} \text { (air) }\end{array}$ & $\begin{array}{l}\text { Convective heat loss from the skin } \\
\text { to the environment } \\
\text { Convective heat gain from the environment } \\
\text { to body skin }\end{array}$ \\
\hline Radiant temperature & $\begin{array}{l}\text { Radiant heat exchange } \\
\text { between skin } \\
\text { and environment }\end{array}$ & $\begin{array}{l}\text { In the sun, radian temperature can easily } \\
\text { exceed temperature, which results in radiant } \\
\text { heat transfer from the environment to the skin }\end{array}$ \\
\hline Surface temperature & $\begin{array}{l}\text { Conductive heat } \\
\text { exchange (minor role) }\end{array}$ & Not applicable \\
\hline Air humidity & $\begin{array}{l}\text { Evaporative heat } \\
\text { loss or gain }\end{array}$ & $\begin{array}{l}\text { The amount of moisture (not relative humidity) } \\
\text { in the air determines whether moisture (sweat) } \\
\text { in vapor from flows from the skin to the } \\
\text { environment or vice versa, evaporation of sweat } \\
\text { is the most important avenue for the body to } \\
\text { dissipate its surplus heat }\end{array}$ \\
\hline Wind speed & $\begin{array}{l}\text { Convection and } \\
\text { evaporation }\end{array}$ & $\begin{array}{l}\text { Heat exchange increases with increasing } \\
\text { wind speed }\end{array}$ \\
\hline
\end{tabular}

As a matter of fact, by increasing the urbanization and construction, the percentage of UHI formation and then the impacts of UHI on human health increase.

The environmental factors listed in Table 4 influence the heat loss components and should therefore be considered in assessing heat stress.

Figure 7 shows that due to growing urban areas, temperature and air pollution increase which cause UHI intensity with direct effects on human health. Therefore, higher temperature and air pollution can widely affect human health.

\subsection{Heat stress}

The incidence and severity of many health problems increase with increasing temperature. As temperature increase, the body expends added energy to keep cool. The most immediate consequence, if the body's temperature rises above $41^{\circ} \mathrm{C}$, is heat stroke. This disturbance to the temperature-regulating mechanism of the body results in fever, hot and dry skin, rapid pulse, and sometimes progresses to delirium and coma. Also, temperature stress can exacerbate many existing health conditions including cardiovascular and cerebrovascular disease, diabetes, chronic obstructive pulmonary disease, pneumonia, asthma, and influenza. Mortality from such diseases, especially among children and the elderly, increases dramatically during periods of unusually hot weather [17].

Extreme heat poses a threat to human life, health and well-being in a variety of ways. Table 5 shows extreme heat and its associated health impacts. It can damage health by leading to an increased risk of injury, illness, stress-related disorders and death. In addition, changing temperature and other weather variables also affect human health. Weather variables are associated with hospital admissions for respiratory diseases over certain periods [20, 21]. 


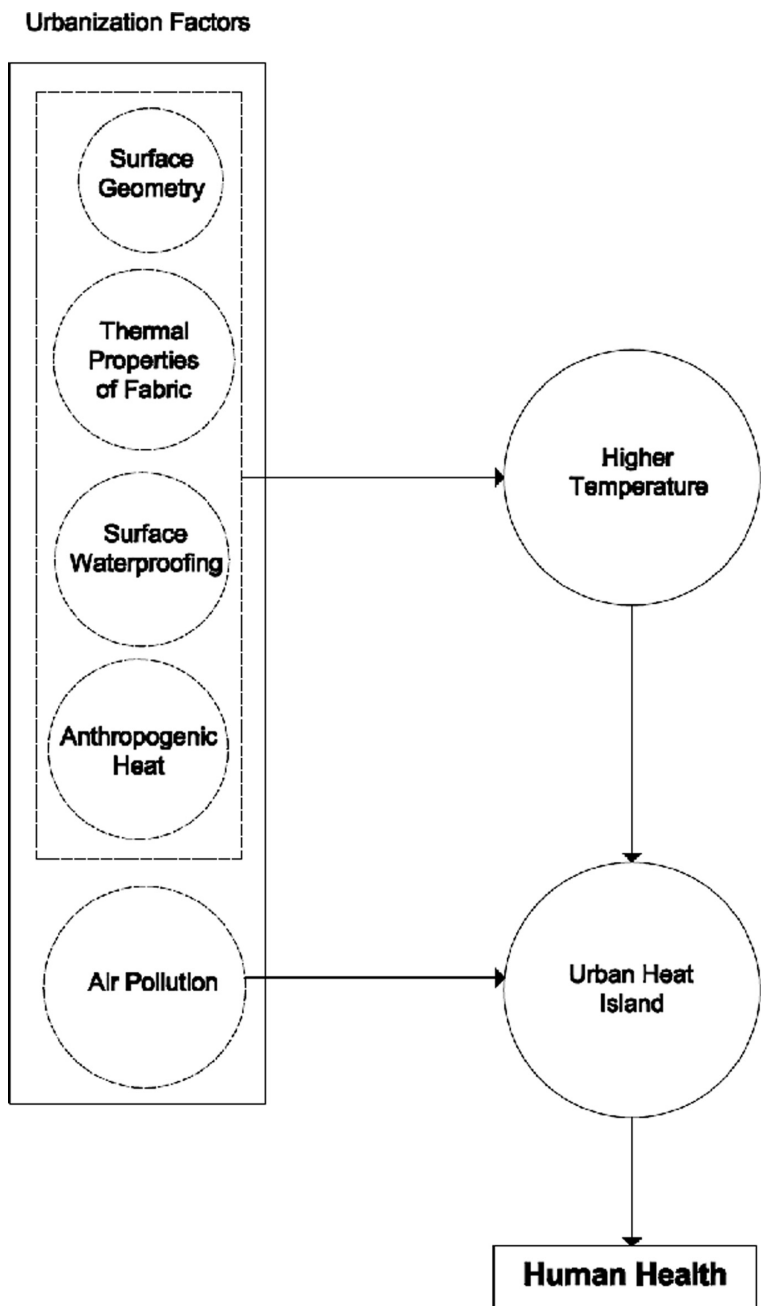

Figure 7: The process of UHI formation and its effects on human health.

\subsection{Effects of air pollution on health}

Air pollution of Tehran should be seriously taken into account. For more than 30 years, officials are concerned about traffic problems that also endanger the health of Tehran's residents. Air pollution, an exacerbating factor for pulmonary health conditions such as asthma and cardiorespiratory disorders, will probably increase as a result of climate change [17]. This will increase emissions of particulates (a cause of respiratory problems), toxic aromatic hydrocarbons (carcinogens), and sulfur dioxide (acid rain).

Tehran has suffered from poor air quality since the oil boom decade of 1970s, but a rapid population growth in the past 15 years has made matters even worse. On some days, the pollution loading of the atmosphere is so high that the impressive Alborz Ranges become invisible from most vantage points [22]. It has been recently stated by Tehran's Clean Air Committee that 10,000 people die 
Table 5: Extreme heat and its associated health impacts [19].

\begin{tabular}{|c|c|c|c|}
\hline $\begin{array}{l}\text { Extreme weather } \\
\text { event }\end{array}$ & $\begin{array}{l}\text { Health impact } \\
\text { pathway(s) }\end{array}$ & $\begin{array}{c}\text { Potential } \\
\text { health effects }\end{array}$ & $\begin{array}{l}\text { Populations } \\
\text { at higher risk }\end{array}$ \\
\hline Extreme heat & $\begin{array}{l}\text { Body temperatures } \\
\text { are elevated beyond } \\
\text { normal range } \\
\text { Increased growth and } \\
\text { abundance of disease } \\
\text { causing organisms } \\
\text { and/or vectors } \\
\text { Air quality is negatively } \\
\text { affected }\end{array}$ & $\begin{array}{l}\text { Dehydration } \\
\text { Heat-related illnesses (heat } \\
\text { stroke, fainting, heat cramps, } \\
\text { heat rash) } \\
\text { Existing medical problems } \\
\text { made worse, such as asthma } \\
\text { and allergies } \\
\text { Physical and mental stress } \\
\text { Respiratory and cardiovascular } \\
\text { disorders } \\
\text { Food-borne diseases } \\
\text { Vector-borne infectious } \\
\text { diseases }\end{array}$ & $\begin{array}{l}\text { Young children } \\
\text { Seniors (especially those } \\
\text { who are bed-ridden, } \\
\text { unable to care for } \\
\text { themselves or socially } \\
\text { isolated) } \\
\text { Chronically ill individuals } \\
\text { People with compromised } \\
\text { health status } \\
\text { People living in areas } \\
\text { with poor air quality } \\
\text { People working } \\
\text { or exercising outdoors } \\
\text { People without access to } \\
\text { air conditioning } \\
\text { People on certain } \\
\text { medications }\end{array}$ \\
\hline
\end{tabular}

every year due to air pollution related cardio-pulmonary disease. Shafie-Pour and Ardestani [23] estimated that the total health damage from air pollution in major urban centers of Iran cost US\$7 billion; equivalent to $8.4 \%$ of Gross Domestic Productivity (GDP); clearly making air quality a serious concern for this country.

\section{HEALTHY ENVIRONMENT}

No city today has quite healthy environment. There are some sources of pollutions in the city which can make it unhealthy. The most important of them are air pollution and higher temperature, can affect health directly. Therefore, for achieving a healthy environment and reducing UHI effects, this article suggests three main recommendations from urban design perspective. As a matter of fact, by mitigation of UHI intensity through improving some urban design elements, it will be possible to move one step forward healthy environment and decrease the negative impacts of UHI on human health.

\subsection{Achieve appropriate transportation for mitigating air pollution}

The unrelenting growth of transport has become one of the greatest environmental threats facing Tehran, and a great obstacle to achieving sustainable development. The problem of congestion on the roads and environmental pollution are still with us in the 21 century, and condition may get worse before they improve.

Therefore, this paper is recommended following suggestions in order to achieve the sustainable transportation and mitigate air pollutions in the city:

- Make streets, lanes and paths more pleasant for walking (shaded path ways exclusively designated for pedestrians and bicycles can be provided to encourage these modes of transport). 
- Bring services and facilities closer together to reduce need to drive and reduce distances.

- Expand bus and metro lane networks.

- Improve quality standards for bus and rail services.

- Encourage people to use public transport.

\subsection{Providing appropriate landscape}

Providing an appropriate landscape in urban and building scales can contribute to energy consumption reduction. The impact of an appropriate landscape around a building on energy consumption and surrounding temperature regime is very important. Landscaping the surrounding area is a basic criterion to improving the external climatic conditions. As mentioned by Santamouris [4], shading from trees can

1. significantly decrease the energy required for cooling;

2. decrease the rate of heat convection inside buildings because of shaded surfaces that have a lower temperature; and

3. decrease the radiation exchange of the wall with the sky.

Sailor [24] considers that the low evaporative heat flux in cities is the most significant factor in the development of an UHI. When vegetation is placed on urban surfaces, thermal balances can shift to new conditions that are closer to the cooler conditions of rural areas. It is estimated that $1,460 \mathrm{~kg}$ of water is evaporated from an average tree during a sunny summer day, which consumes about $860 \mathrm{MJ}$ of energy; this offers a cooling effect outside a building that is equal to five average air conditioners [4]. In addition, water surfaces and wind channeling through natural or artificial barriers reduce the effect of solar radiation in summer, whereas in winter they shelter the building.

Furthermore, to reduce energy consumption, various types of trees and vegetation, as well as bodies of water, in different parts of the city and buildings must be considered.

Therefore, this paper recommends using green spaces in vertical and horizontal layers.

Vertical green spaces: green spaces in some parts of buildings and city that provide natural ventilation or appropriate landscapes in different layers or floors of buildings with a multiuse function can significantly decrease the energy required to cool buildings.

Horizontal green spaces: green spaces on roofs absorb heat, decrease the tendency towards thermal air movement and filter air movement.

Through the daily dew and evaporation cycle, plants on vertical and horizontal surfaces are able to cool cities during hot summer months. In the process of evapotranspiration, plants use heat energy from their surroundings when evaporating water.

\subsection{Increasing the albedo of building materials}

The albedo of a surface is responsible for the amount of solar radiation it absorbs. High albedo building surfaces (such as white ones) have been proven to cool down urban temperatures [25-27].

The selection of materials is significant for the thermal performance of building facades and the urban thermal environment. A material with high albedo can reduce the solar heat gain during the daytime. The surface temperature of the material is lower than that of a material with low albedo. Since the urban ambient temperature is associated with the surface temperatures of the building facade, lower surface temperature can obviously help decreasing the ambient air temperature and eventually contribute to better urban thermal environment. 
The results derived from a simulation revealed the variance of the surface temperatures of the building facades with different colors. The dark-color material can be up to around $7^{\circ} \mathrm{C}$ higher than the ambient air temperature whereas the light-color one is only around $2-3^{\circ} \mathrm{C}$ higher than the air temperature. A simulation reveals that the cooling load increases as the color of the façade changes from lighter to darker. A reduction of $7.48 \%$ of cooling energy was achieved when the color of the façade is changed from Alucobond Sparkling black to Alucobond pure white aluminum facade [28].

In multistoried buildings, facade plays a major role in governing the cooling load of the building whereas roof has an important effect mainly on the top floor just below the roof.

Therefore, this paper is recommended using high albedo and light color materials for facades and building covers in order to decrease the ambient air temperature and eventually contribute to better urban thermal environment.

\section{CONCLUSION}

Human health suffers from many aspects of UHI. It can directly impact on thermal stress, leading to cardiovascular and respiratory morbidity and mortality. The urban poor will be particularly subject to negative health effects of heat island. The percentage of the world's population living in cities is expected to increase to $60 \%$ by the second half of this century. This trend will certainly increase the risks to human health from disease and air pollution.

As has been pointed out in this paper, Tehran suffers from climatic alterations, with main characteristic the raised temperatures in the city core, a phenomenon generally known as the heat island effect. Tehran city suffers more from the heat island effect during the hot season. With the morbidity and mortality risks these raised temperatures are responsible for the much greater amounts of cooling energy needed; it is an impossibility to talk about sustainability planning and policies in Tehran metropolitan, unless these temperatures are mitigated.

It has been shown in this paper, that the ways to mitigate the heat island effect in Tehran, without altering the city planning, do exist. The only alterations that need to be done are on the building envelopes. By covering roofs and walls either with higher albedo and evapotranspiring surfaces, urban temperatures can decrease significantly. The latter can lead to greater temperature decreases, due to both plants' higher albedo and evapotranspiration, which acts as a very effective cooler in the Tehran hot summer. By considering a micro-climatic study, the amount of vegetation placed on a building and its position (roofs, walls or both) is a more dominant factor than the orientation of the urban canyon. Canyon geometry plays a more important role than orientation, with green roofs and walls having a fainter thermal impact on wider canyons. Much healthier and more comfortable, from a thermal point of view, outdoors conditions are reached; the thermal sensation zones 'hot' and 'warm' are not reached when urban roofs and walls are covered with vegetation, leading to more pleasant and safer temperatures for urban dwellers. The other point which might be useful for mitigating the effects of Tehran UHI is to improve public transportation systems.

Saving energy and decreasing energy demands, promoting environmental quality and air quality and protecting human health in urban spaces will be possible by decreasing the effects of UHI.

\section{REFERENCES}

[1] Intergovernmental Panel on Climate Change (IPCC), Summary for Policymakers. Climate Change 2007: The Physical Science Basis, Working Group I Contribution to the Intergovernmental Panel on Climate Change Fourth Assessment Report, eds S. Solomon, D. Qin, M. Manning, Z. Chen, M. Marquis, et al., Cambridge University Press: Cambridge, UK, 2007.

[2] Intergovernmental Panel on Climate Change (IPCC), potential impacts of climate change: human settlements; energy, transport and industrial sectors; human health; air quality and changes in 
ultraviolet-B radiation. Working Group II Contribution to the Intergovernmental Panel on Climate Change (A. Izrael, chair,. Geneva WMO/UNEP), p. 34, 1990.

[3] Emmanuel, M.R., An Urban Approach to Climate-Sensitive Design; Strategies for the Tropics, Spon Press: London, 2005.

[4] Santamouris, M., Energy and Climate in the Urban Built Environment, James \& James Publication: London, 2001.

[5] Oke, T.R., Boundary Layer Climates, 2nd edn, Methuen and Co. Ltd.: New York, 1987.

[6] Oke, T.R., Canyon geometry and the nocturnal urban heat island: comparison of scale model and field observations. Journal of Climatology, 1, pp. 237-254, 1981. doi:10.1002/ joc. 3370010304

[7] Habibi, S.M. \& Hourcade, B., Atlas of Tehran Metropolis, Pardazesh va Barnamerizi-e Shahri Publications: Tehran, Iran, 2005.

[8] Bahrainy, H., Application of meteorology of air pollution in urban design of the city of Tehran. Journal of Environmental Studies: Scientific Report Series of Environment, 22(18), pp. 17-31, 1997.

[9] Alijani, B. \& Safavi, S.Y., Study geographical factors in Tehran air pollution. Geographical Studies Journal, 58, pp. 99-112, 2007.

[10] Madanipour, A., Tehran: the Making of a Metropolis, John Wily \& Sons: England, 1998.

[11] Hastaie, P., Air Pollution Countermeasures in Tehran, http://www.worldbank.org/html/fpd/ transport/utsr/budapest/background/tehran.pdf, 2004.

[12] Peterson, J.T., The climate of cities: a survey of recent literature. Climate in Review, ed. G. McBoyle, pp. 264-285, 1973.

[13] Alexandri, E. \& Jones, P., Sustainable urban future in southern Europe - what about the heat island effect? European Regional Science Association Conference Papers, Vienna, Austria, 2006.

[14] Givoni, B., Climate Considerations in Building and Urban Design, John Wiley \& Sons: Canada, 1998.

[15] Sepehri, J. \& Zarei, P., Sport and heat island phenomenon in cities. Proc. of the 1st National Conf. on City and Sport, Tehran, Iran, 2007.

[16] Lee, D.O., Urban climates. Progress in Physical Geography, 8(4), pp. 1-31, 1984. doi:10.1177/030913338400800101

[17] Hardy, J.T., Climate Change: Causes, Effects, and Solutions, John Wiley \& Sons: England, 2003.

[18] Wong, N.H. \& Chen, Y., Tropical Urban Heat Islands: Climate, Buildings and Greenery, Taylor \& Francis Press: London and New York, 2009.

[19] World Health Organization (WHO), Heat-waves: risks and responses. Health and Global Environmental Change (Series, No. 2). Geneva: German Weather Service (DWD). London School of Hygiene and Tropical Medicine and WHO/Europe, 2004.

[20] Makie, T., Harada, M., Kinukawa, N., Toyoshiba, H., Yamanaka, T. et al., Association of meteorological and day-of-the-week factors with emergency hospital admissions in Fukuoka, Japan. International Journal of Biometeorology, 46(1), pp. 38-41, 2002. doi:10.1007/s00484001-0110-2

[21] Hajat, S., Armstrong, B., Gouveia, N. \& Wilkinson, P., Comparison of mortality displacement of heat-related deaths in Delhi, Sao Paulo and London. Epidemiology Journal, 15(4), p. 94, 2004.

[22] Appelhans, T. et al., Mesoscale controls on particulate matter pollution for a mega-city in a semi-arid mountainous environment: Tehran, Iran. Proc. of the 13th Int. Conf. on Mountain Meteorology \& 17th Int. Conf. on Applied Climatology, Canada, 2008. 
[23] Shafie-Pour, M. \& Ardestani, M., Environmental damage costs in Iran by the energy sector. Energy Policy, 35, pp. 4413-4423, 2007. doi:10.1016/j.enpol.2007.03.008

[24] Sailor, D.J., Sensitivity of coastal meteorology and air quality to urban surface characteristics, Preprints of the Eighth Joint Conference on the Applications of Air Pollution Meteorology on American Meteorological Society, vol. 8, Boston, MA, pp. 286-293, 1994.

[25] Akbari, H., Bretz, S., Kurn, D.M. \& Hanford, J., Peak power and cooling energy savings of high-albedo roofs. Energy and Buildings, 25, pp. 117-126, 1997. doi:10.1016/S0378-7788(96)01001-8

[26] Taha, H., Urban climates and heat islands: albedo, evapotranspiration, and anthropogenic heat. Energy and Buildings, 25, pp. 99-103, 1997. doi:10.1016/S0378-7788(96)00999-1

[27] Konopacki, S., Gartland, L., Akbari, H. \& Rainer, L., Demonstration of Energy Savings of Cool Roofs. A Report Prepared for the U.S. Environmental Protection Agency, Heat Island Project, University of California, Berkeley, 1998.

[28] Wong, N.H., A Study of the Urban Heat Island in Singapore. A Report of Heat Island Project, National University of Singapore, 2002. 